\title{
An Experimental Study of Co-Axial Dielectric Barrier Discharge for Ozone Generation
}

\author{
G. P. Panta, D. P. Subedi, H. B. Baniya, \\ A. P. Papadaki and S. Dhungana
}

Journal of Nepal Physical Society

Volume 6, Issue 1, June 2020

ISSN: 2392-473X (Print), 2738-9537 (Online)

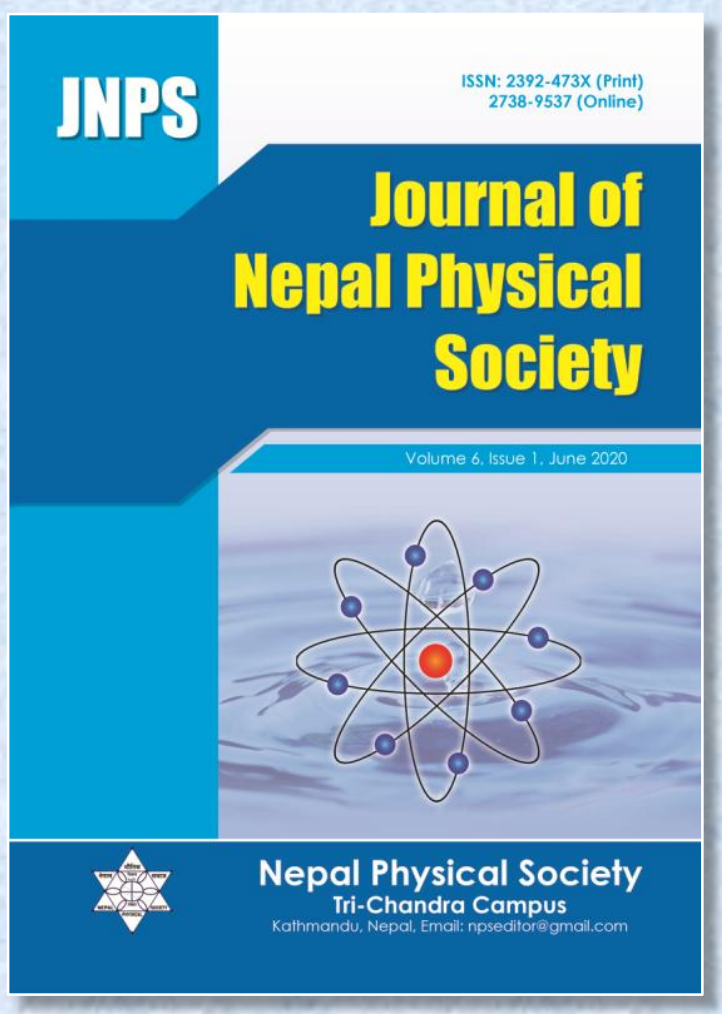

Editors:

Dr. Binod Adhikari

Dr. Manoj Kumar Yadav

Mr. Kiran Pudasainee

JNPS, 6 (1), 84-89 (2020)

DOI: http://doi.org/10.3126/jnphyssoc.v6i1.30554

Published by:

Nepal Physical Society

P.O. Box: 2934

Tri-Chandra Campus

Kathmandu, Nepal

Email: npseditor@gmail.com 


\title{
An Experimental Study of Co-Axial Dielectric Barrier Discharge for Ozone Generation
}

\author{
G. P. Panta ${ }^{1 *}$, D. P. Subedi ${ }^{1}$, H. B. Baniya ${ }^{1,2}$, A. P. Papadaki ${ }^{3}$ and S. Dhungana ${ }^{1}$ \\ ${ }^{1}$ Department of Physics, School of Science, Kathmandu University, Dhulikhel, Kavre, PO Box No. 6250, Nepal. \\ ${ }^{2}$ Department of Physics, Tri-Chandra Multiple Campus, Tribhuvan University, Nepal. \\ ${ }^{3}$ Department of Electrical Engineering, School of Engineering, Frederick University, Nicosia, Cyprus. \\ "Corresponding Emails: gobindapanta@yahoo.com, gppanta@ku.edu.np
}

Received: 10 Mar., 2020; Revised: 12 May, 2020; Accepted: 28 Jun., 2020

\begin{abstract}
In this research work, co-axial cylindrical dielectric barrier discharge (CCDBD) system has been used as a ozone generator for ozone production with air as a working gas. The breakdown of air was generated inside the reactor by using low line frequency of $50 \mathrm{~Hz}$ and high AC voltage power supply system. The variation of air flow rate $(\mathrm{Q})$ was taken from 10 to $16 \mathrm{l} / \mathrm{min}$ in this experiment. The $\mathrm{O}_{3}$ concentration denoted by $\mathrm{C}\left(\mathrm{O}_{3}\right)$ decreases with increasing the rate of flow of air at fixed discharge time and applied voltage. When discharge time $(\mathrm{t})$ increases, $\mathrm{C}\left(\mathrm{O}_{3}\right)$ increases at fixed applied voltage. $\mathrm{C}\left(\mathrm{O}_{3}\right)$ also increases with increasing applied voltage (V) for constant discharge time. If the gap space between the electrodes increases then $\mathrm{C}\left(\mathrm{O}_{3}\right)$ increases. We have used glass tube reactor for this work having internal diameter of $18 \mathrm{~mm}$ and copper, brass and iron electrodes of diameter $8 \mathrm{~mm}$. It was estimated that $\left.\mathrm{C}_{(\mathrm{O}}\right)$ found higher for copper electrode than both brass and iron electrode for certain discharge time, applied voltage and reactor diameter.
\end{abstract}

Keywords: Applied Voltage, CCDBD, Electrodes, Ozone Analyzer BMT 964, $\mathrm{O}_{3}$ concentration.

\section{INTRODUCTION}

Atmospheric pressure non-thermal (cold) plasma technology offers an attractive perspective in industrial processes due to the elimination of expensive vacuum equipment, easier handling of the samples [1, 2]. DBD reactor can produce active species without using expensive vacuum systems. Normally, corona discharge generates nitrogen species whereas DBD produces oxygen species. The emission of UV-light, formation of radicals and charged particles contribute to the destruction of microorganisms in plasmas [3]. DBD is generally generated in the filamentary mode when worked at atmospheric pressure and is used for ozone generation [4]. DBD finds its applications in excimer lamps and plasma screens, carbon dioxide laser, surface activation and treatment, waste gas treatment $[3,4,5]$. AC source supply of 50 or $60 \mathrm{~Hz}$ line frequency having a step up transformer can be the best choice for formation of ozone in ambient air DBDs [6]. Due to strong oxidizing property of ozone produced in DBD and environmentally friendly nature, it looks an increasing demand for several applications such as in medicine, water treatment, food chemistry, plasma assisted combustion, flue gas treatment, algae, bacteria, viruses, cysts, spores killing and removing VOCs, odor treatment, purification of ambient air, disinfecting food products to increase shelf life [7, 8]. The interaction of high energy electrons with the $\mathrm{O}_{2}$ molecules within the inter electrode space give rise to the dissociation of $\mathrm{O}_{2}$ molecules, when air is passed through the DBD reactor [9]. $\mathrm{O}_{3}$ is a relatively unstable molecule compared to $\mathrm{O}_{2}$, which is very relatively stable and $\mathrm{O}_{3}$ is 12.5 times more soluble than $\mathrm{O}_{2}$ in water. $\mathrm{O}_{3}$ naturally can be formed by UV radiation, through the method of sunlight, which can reduce $\mathrm{O}_{2}$ in the air and it is smellirritating, colorless gas [10]. The oxidation potential of $\mathrm{O}_{3}$ is $2.07 \mathrm{~V}$ and has relatively higher disinfection potential than chlorine of oxidation potential $1.36 \mathrm{~V}$ and other oxidizing species $[11,12,13]$. The $\mathrm{O}_{2}$ breaks down into two radical $\mathrm{O}$ then reacts with $\mathrm{O}_{2}$ to form $\mathrm{O}_{3}[14,15,16]$. A remarkable progress has been made in the production and applications of atmospheric pressure cold plasma DBD for $\mathrm{O}_{3}$ 
formation [17]. The main role of electrons produced in electrical discharge is to excite and dissociate $\mathrm{O}_{2}$ molecules [7, 14].

$\mathrm{e}^{-}+\mathrm{O}_{2} \rightarrow \mathrm{O}+\mathrm{O}+\mathrm{e}$

The plasma chemistry for the chemical reaction of $\mathrm{O}_{3}$ formation is given by $[7,14]$ :

$$
\begin{aligned}
& \mathrm{O}+\mathrm{O}+\mathrm{M} \rightarrow \underset{2}{\mathrm{O}}+\mathrm{M} . \\
& \mathrm{O}+\mathrm{O}_{2}+\mathrm{M} \rightarrow \mathrm{M}+\mathrm{O}_{3}
\end{aligned}
$$

$\mathrm{M}$ denotes $\mathrm{N}_{2}$ or $\mathrm{O}_{2}$ in air discharge.

The purpose of this work is to determine the effect of the air flow rate, applied voltage, geometry of the central electrodes and discharge time on the generation of $\mathrm{O}_{3}$ by CCDBD in cylindrical glass tube reactor which has designed according to DBD technique with air as a working gas.

\section{EXPERIMENTAL DESCRIPTION}

The generation of ozone $\left(\mathrm{O}_{3}\right)$ in CCDBD has been developed and an attempt to obtain the optimum condition for higher ozone concentration in cylindrical double dielectric barrier glass tube reactor at atmospheric pressure is conducted. The CCDBD reactor for generation of ozone in laboratory at atmospheric pressure in working air environment and its measurement is shown in Fig. 1. AC high voltage source having voltage of $0-18 \mathrm{kV}$ and low frequency was used to CCDBD generator of internal diameter $18 \mathrm{~mm}$ and its $1 \mathrm{~mm}$ thickness. The central electrodes were made up of copper, brass and iron rods of diameter $8 \mathrm{~mm}$ fixed inside glass tube. Aluminum sheet wrapped outside the glass tube acted as outer electrode.

For this experiment, air was given by air blower and passes inside the chamber through the gap space of reactor. The $\mathrm{O}_{3}$ concentration $\mathrm{C}\left(\mathrm{O}_{3}\right)$ was measured by using ozone analyzer BMT 964 device after the discharge was developed inside the CCDBD reactor. The BMT 964 can measure ozone concentration from 0 to $5000 \mathrm{ppmv}$. The different central electrodes and reactor were used to explain the effect of the geometry on ozone concentration inside the discharge chamber.

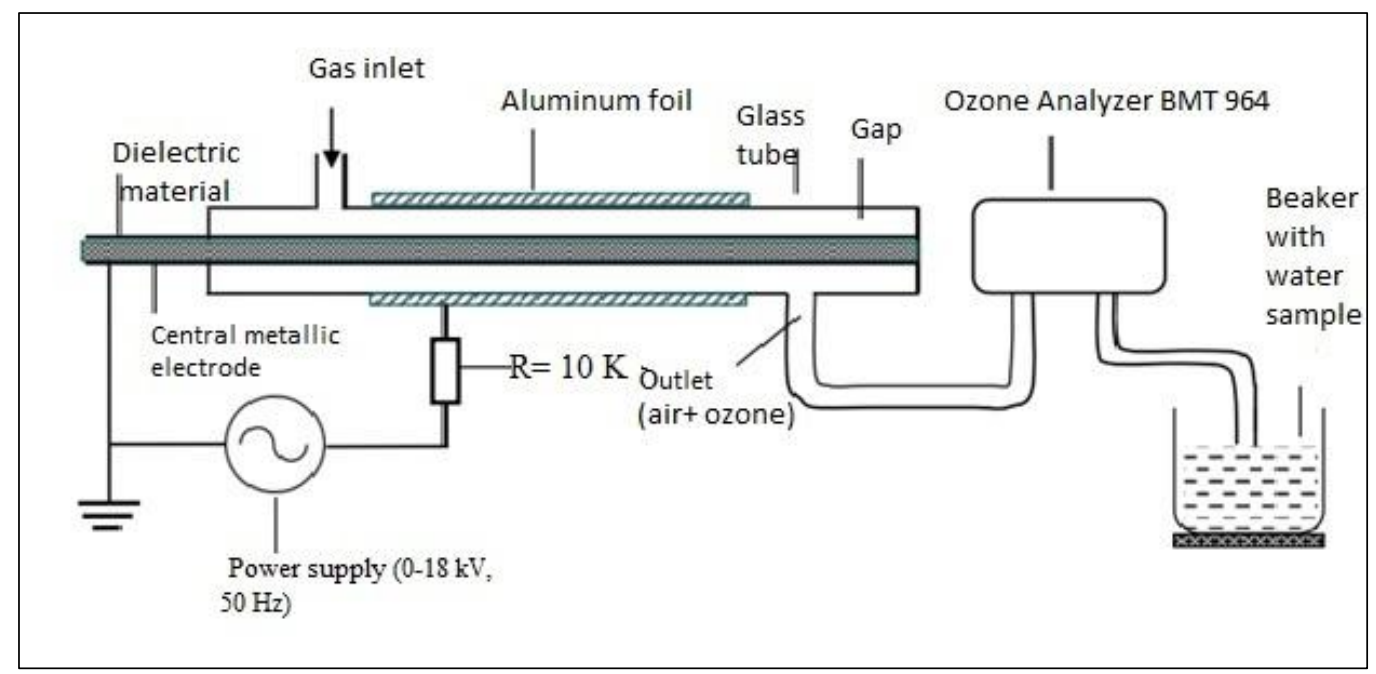

Fig. 1: Schematic diagram of experimental set -up for $\mathrm{O}_{3}$ generation $[8,15]$

\section{RESULTS AND DISCUSSION}

Fig. 2 shows the variation of $\mathrm{O}_{3}$ concentration with rate of flow of air at applied voltage $14.87 \mathrm{kV}$ for constant discharge time of 7 minutes for copper, brass and iron central electrodes of diameter $8 \mathrm{~mm}$. From Fig. 2, the $\mathrm{C}\left(\mathrm{O}_{3}\right)$ becomes fall with rising flow of air which is due to complex composition of air and containing of different species such as $\mathrm{H}_{2}$, $\mathrm{He}, \mathrm{N}_{2}, \mathrm{O}_{2}$, Ar etc. The ozone production is slowly suppressed when flow rate increases because atom $\mathrm{O}$ generated runs out more quickly following the flow rate of the gas that comes out more rapidly. If low number of oxygen molecules per unit volume of air with feed gas air then low $\mathrm{C}\left(\mathrm{O}_{3}\right)$ produces inside the reactor. Less no. of collision of gas atoms with electrons happen due to smaller residence time for high air flow rate to take slightly longer time for saturation. The fluctuations of data for $\mathrm{C}\left(\mathrm{O}_{3}\right)$ was due to the raise in air temperature in the ozonizer. 
This may be due to the fact that when the air flow rate is minimum then it takes longer time to occur the collision between the gas molecules and electrons reducing the number of excited species, which influence the rate of plasma chemical reaction. So, it takes slightly longer time to build of step ionization which is responsible to produce more ozone concentration. There exist an optimum flow rate at which the $\mathrm{C}\left(\mathrm{O}_{3}\right)$ reaches maximum which is the dependence of $\mathrm{C}\left(\mathrm{O}_{3}\right)$ on no. of $\mathrm{O}_{2}$ molecules per unit volume and its residence time inside the ozone generator.

The residence time of the air inside the discharge chamber decreases for higher flow rate of air and then hence probability of collision of $\mathrm{O}_{2}$ molecules with electrons decreases which ultimately reduces the formation of $\mathrm{O}_{3}$. The ozone efficiency also affects by flow of air which is due to the increase in cooling rate and rise in temperature of feed air and also small factor of UV radiation. The air residence time in the reactor reduces, if the air flow rate increases. The $\mathrm{O}_{3}$ formation reaction takes place in the presence of $\mathrm{O}_{2}$ in the reactor by the dissociation of $\mathrm{O}_{2}$ from collisions with electrons. The residence time of the gas in the reaction chamber is inversely proportional to the flow rate when residence time increased giving much sufficient time for a higher $\mathrm{C}\left(\mathrm{O}_{3}\right)$ to be generated. The shorter the residence time of the $\mathrm{O}_{2}$ molecules in the reactor is due to higher flow rate of input gas and faster the $\mathrm{O}_{2}$ molecules reached out from the chamber. Low flow rate will cause $\mathrm{O}_{2}$ molecules to stay longer time duration in the reactor with more dissociation of $\mathrm{O}_{2}$ and increases $\mathrm{O}_{3}$ formation.

When the applied voltage increases the ozone begins to be formed and its concentration increases rapidly with applied voltage for all values of the flow rate. The air flow rate itself also affects the ozone generation efficiency because of increasing cooling rate with air cooled ozone reactor. The ozone concentration is found to be more in copper electrode than brass and iron electrodes in air as a feed gas for all flow rate of air as shown in Fig. 2.

This is because of higher electrical conductivity of copper than brass and iron electrode. From Fig. 2, it is clear that by using low flow rate of air and copper electrode instead of brass and iron electrodes, high concentration of ozone can be produced at low cost, limited power supply, fixed discharge time and fixed diameter of electrode in the ozone reactor.

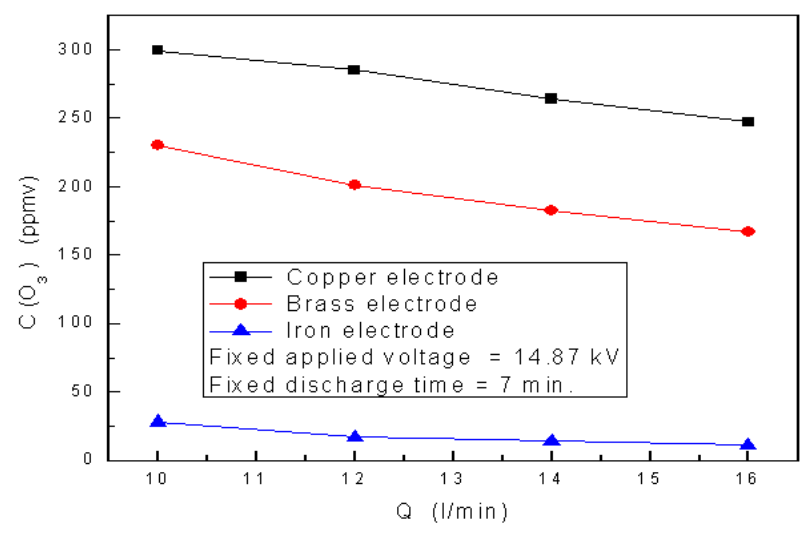

Fig. 2: Plot of $\mathrm{O}_{3}$ concentration $\left.\mathrm{C}_{(} \mathrm{O}_{3}\right)$ with rate of flow of air (Q) for copper, brass and iron electrodes.

Fig. 3 shows the variation of $\mathrm{O}_{3}$ concentration with discharge time at fixed applied voltage $14.87 \mathrm{kV}$ for constant flow rate $81 / \mathrm{min}$ of air for brass, copper and iron central electrodes of diameter $8 \mathrm{~mm}$. From Fig. 3 (a), it can be seen that $\mathrm{C}\left(\mathrm{O}_{3}\right)$ becomes high for as long discharge time and becomes saturated after some discharge times. It is due to the reason that as the discharge time increases, the $\mathrm{O}_{2}$ molecules with the electrons, reducing the number of excited species, which influence the rate of plasma chemical reaction and it takes some time to build step ionization phenomenon which is responsible to produce more $\mathrm{C}\left(\mathrm{O}_{3}\right)$. The $\mathrm{C}\left(\mathrm{O}_{3}\right)$ will be decreasing after saturation of discharge time. This is due to the fact that $\mathrm{O}_{3}$ is highly unstable gas having half- life 10 to 30 minutes and also depends on the temperature generated inside the reactor. When the temperature increases inside the reactor, half- life of ozone decreases. So that $\mathrm{O}_{3}$ decompose to produce $\mathrm{O}_{2}$. In Fig.3 (a), 3 (b) and 3 (c), we can be clearly seen the decrease of ozone concentration when discharge time increases somewhere and after saturation, $\mathrm{C}\left(\mathrm{O}_{3}\right)$ will be decreasing. Fig.3 (b) and 3 (c) demonstrated similar types of trend which is due to the residence time of the feed gas in the chamber. This is due to the increase of $\mathrm{C}\left(\mathrm{O}_{3}\right)$ with increasing non-elastic collisions with $\mathrm{O}_{2}$ molecules. The $\mathrm{C}\left(\mathrm{O}_{3}\right)$ was measured more in copper electrode than brass electrode and iron electrode This is due to the reason that $\mathrm{C}\left(\mathrm{O}_{3}\right)$ increases with increasing amount of non-elastic collisions with $\mathrm{O}_{2}$ molecules. Reaction to the formation of $\mathrm{O}_{3}$ in the discharge forms $\mathrm{O}_{2}$ dissociation due to collision with electrons where at a constant flow rate, based on the number of reactions which is very slower compared to collision of electron dissociation impact. When residence time increases for a reactor to occur then more $\mathrm{O}_{3}$ be 
generated. This is due to the long residence time of the gas on the $\mathrm{O}_{3}$ generator.

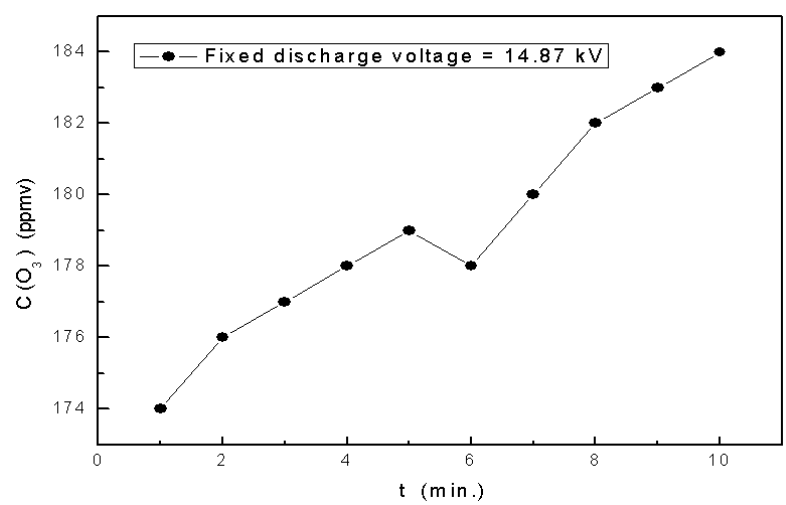

Fig. 3 (a): Plot of $\mathrm{O}_{3}$ concentration $\mathrm{C}\left(\mathrm{O}_{3}\right)$ with discharge time (t) for brass electrode.

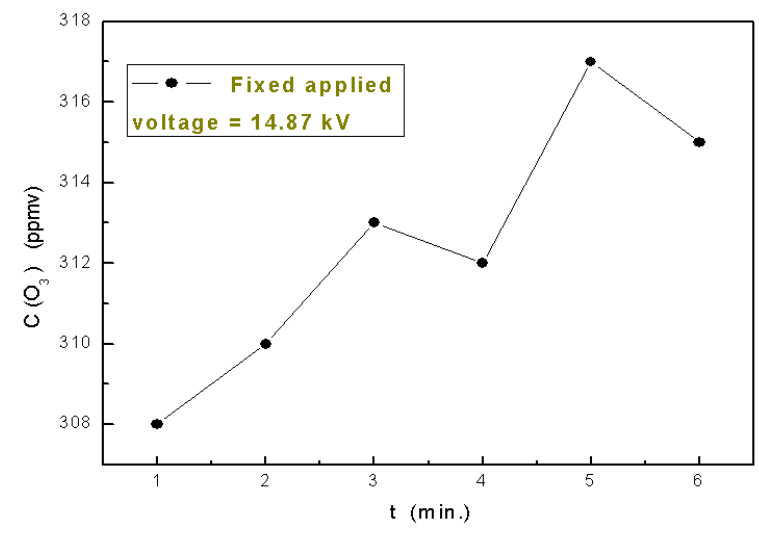

Fig. 3 (b): Plot of $\mathrm{O}_{3}$ concentration $\mathrm{C}\left(\mathrm{O}_{3}\right)$ with discharge time ( $t$ ) for copper electrode.

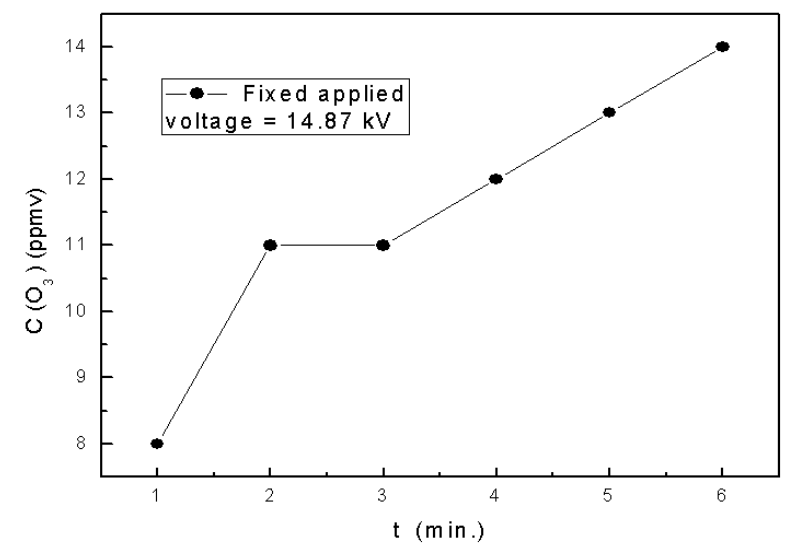

Fig. 3 (c): Plot of $\mathrm{O}_{3}$ concentration $\mathrm{C}\left(\mathrm{O}_{3}\right)$ with discharge time $(t)$ for iron electrode.

Fig. 4. shows the variation of $\mathrm{C}\left(\mathrm{O}_{3}\right)$ with applied voltage at fixed discharge time of 4 minutes at fixed flow rate $81 / \mathrm{min}$ of air for brass, copper and iron central electrodes of diameter $8 \mathrm{~mm}$ using in a double dielectric glass having thickness $1 \mathrm{~mm}$ and internal diameter of reactor $18 \mathrm{~mm}$. From Fig. 4 (a), If applied voltage increases, $\mathrm{C}\left(\mathrm{O}_{3}\right)$ increases at fixed flow rate of air for brass electrode at fixed discharge time. The collision of the electrons with $\mathrm{O}_{2}$ molecules inside the discharge chamber increases with increasing applied voltage and energy density. High voltages provide enough energy for electrons to ionize and dissociate $\mathrm{O}_{2}$ molecules into atomic $\mathrm{O}$ and high enough electric field can accelerate electrons, molecules, or ions causing non-elastic collisions and finally augmenting the number of molecules ionized, radicalized, excited also under this condition, the ionization, excitation, dissociation process can be continued. Collisions accompany this electron movement with $\mathrm{O}_{2}$ molecules which causes ionization and dissociation, so the number of charges will increase. $\mathrm{C}\left(\mathrm{O}_{3}\right)$ was found minimum tend to zero below the applied voltage $11 \mathrm{kV}$ and it increased and found maximum at the applied voltage of $17.22 \mathrm{kV}$ for brass electrode as shown in Fig. 4 (a). After comparison, similar types of trend has obtained in Fig. 4 (b) and 4 (c) as well. For the same applied voltage and discharge time at constant flow rate of air, ozone concentrations are different. $\mathrm{C}\left(\mathrm{O}_{3}\right)$ was observed higher in copper electrode than brass and iron electrodes at same condition. So, from this experiment, it is clear that once can use copper electrode instead of two other electrodes for the production of high $\mathrm{C}\left(\mathrm{O}_{3}\right)$ inside the ozone reactor because of high electrical conductivity of copper than other two materials. From this work, it is also clear that proper choice of central electrode is also equally play an important role for the production of high $\mathrm{C}\left(\mathrm{O}_{3}\right)$ for limited power supply, discharge time, low cost and effective production of $\mathrm{O}_{3}$ for its various applications.

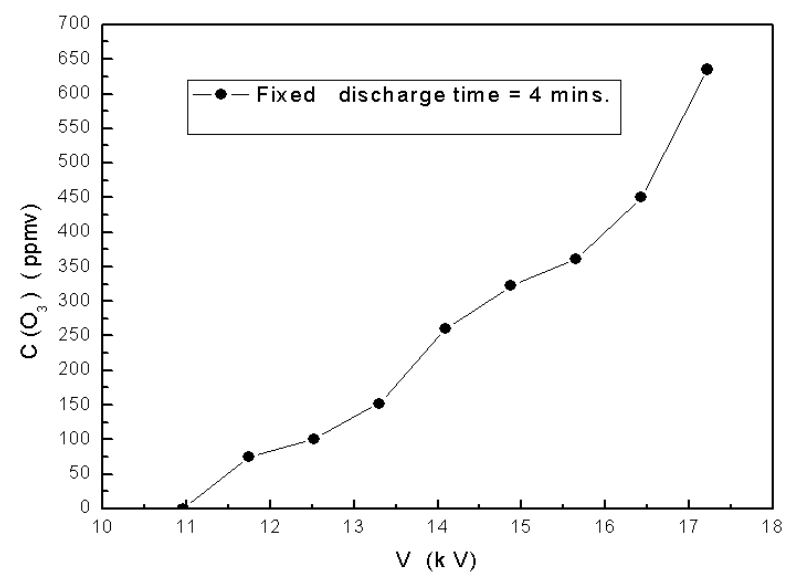

Fig. 4 (a): Plot of $\mathrm{O}_{3}$ concentration $\left.\mathrm{C}_{3} \mathrm{O}_{3}\right)$ with applied voltage $(V)$ for brass electrode. 


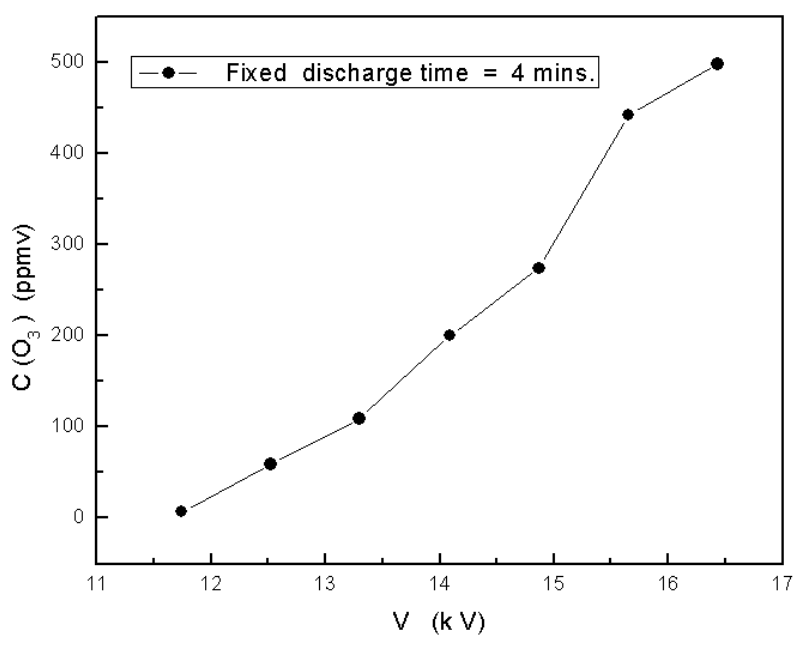

Fig. 4 (b): Plot of $\mathrm{O}_{3}$ concentration $\mathrm{C}\left(\mathrm{O}_{3}\right)$ with applied voltage ( $V$ ) for copper electrode.

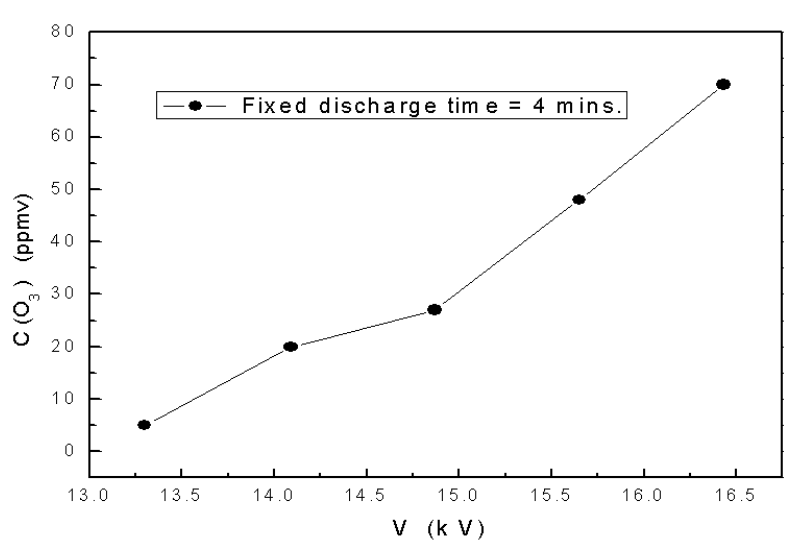

Fig. 4 (c): Plot of $\mathrm{O}_{3}$ concentration $\left.\mathrm{C}_{(} \mathrm{O}_{3}\right)$ with applied voltage (V) for iron electrode.

\section{CONCLUSIONS}

The variation of $\mathrm{C}\left(\mathrm{O}_{3}\right)$ with discharge time and flow of air was studied at a constant applied voltage. It was found that the $\mathrm{C}\left(\mathrm{O}_{3}\right)$ produced, increases with increasing voltage with the fixed discharge time. The $\left.\mathrm{C} \mathrm{O}_{3}\right)$ also increases with increasing discharge time in fixed applied voltage. The $\mathrm{C}\left(\mathrm{O}_{3}\right)$ increases with increasing gap space between the electrodes. But this $\mathrm{C}\left(\mathrm{O}_{3}\right)$ decreases with increasing the air flow rate. It is clear that for low cost production of $\mathrm{O}_{3}$ yield, smaller reactor and larger inner electrode can be investigated and also for small diameter of $\mathrm{O}_{3}$ generator, there exists an optimum inner electrode diameter. The $\mathrm{O}_{3}$ reactor has been designed and used copper, brass and iron as central electrodes and air as a feed gas to produce $\mathrm{O}_{3}$. The $\mathrm{C}\left(\mathrm{O}_{3}\right)$ was higher when using copper electrode in air than brass and iron electrodes for fixed discharge time, applied voltage and central electrodes diameter. For the generation of high $\mathrm{C}\left(\mathrm{O}_{3}\right)$, residence time of gas need to increase inside a DBD reactor. Although copper electrode has high electrical conductivity and can produce high $\mathrm{C}\left(\mathrm{O}_{3}\right)$ but brass electrode is used for the generation of $\mathrm{O}_{3}$ due to its high mechanical strength and electrical resistance in the $\mathrm{O}_{3}$ generator.

\section{ACKNOWLEDGEMENT}

The authors would like to thank Plasma Physics Laboratory (PPL), Department of Physics, School of Science, Kathmandu University for making opportunity to do this work.

\section{REFERENCES}

[1] Baniya, H. B., Guragain, R. P., Baniya, B., Qin, G. \& Subedi, D. P. Improvement of hydrophilicity of polyamide using atmospheric pressure plasma jet. Journal of Physical Sciences (BIBECHANA), 17, 133-138 (2020).

[2] Subedi, D. P., Tyata, R. B., Shrestha, R., \& Wong, C. S. An experimental study of atmospheric pressure dielectric barrier discharge in argon. AIP Conference Proceedings, 103, 103108 (2014).

[3] Bellebna, Y. \& Tilmatine, A. Application of dielectric surface barrier discharge for air disinfection. Acta Electrotechnica et Informatica, 13 (3), 22-26 (2013).

[4] Qin, Y., Qian, S., Wang, C., \& Xia, W. Effects of nitrogen on ozone synthesis in packed-bed dielectric barrier discharge. Plasma Science and Technology, 20, 1-6 (2018).

[5] Boonduang, S. \& Limsuwan, P. Effect of generating heat on ozone generation in dielectric cylinder-cylinder DBD ozone generator. Energy and Power Engineering, 5, 523- 527 (2013).

[6] Al-Jobouri, H. H. \& Ismaeel, H. O. Design an ozone generator by using dielectric barrier discharge. Journal of Al-Nahrain University, 17 (1), 89-94 (2014).

[7] Yuan, D., Wang, Z., He, Y., Xie, S., Lin, F., Zhu, Y., \& Cen, K. Ozone production with Dielectric barrier discharge from air: The influence of pulse polarity. Ozone: Science \& Engineering, (2018), 1-9 (2018).

[8] Shrestha, R., Joshi, U. M., \& Subedi, D. P. Experimental study of ozone generation by atmospheric pressure dielectric barrier discharge. International Journal of Recent Research and Review, 8(4), 24-29 (2015).

[9] Subedi, D. P., Tyata, R. B., Khadgi, A., \& Wong, C. S. Physicochemical and microbiological 
analysis of drinking water treated by using ozone. Sains Malaysiana, 41(6), 739 - 745 (2012).

[10] Hsieh, P. F. \& Wen, T. Y. Evaluation of ozone removal by spent coffee grounds. Scientific Reports, 10 (124), (2020).

[11] Bellebna, Y., R. Ouiddir, R., Nemmic, S., \& Tilmatine, A. Application of dielectric surface barrier discharge for food storage. Leonardo Journal of Sciences, 26, 17-28 (2015).

[12] Nur, M., Supriati, A., Setyaningrum, D. H., Gunawan., G., Munir, M., \& Sumariyah, S. Ozone generator by using dielectric barrier discharge plasma technology with spiral-cylinder configuration: Comparison between oxygen and air as sources. Berkal Fisika, 12 (2), 69-76 (2009).

[13] Tay, W., Yap, S., \& Wong, C. Electrical characteristics and modeling of a filamentary dielectric barrier discharge in atmospheric air. Sains Malaysiana, 43(4), 583-594 (2014).
[14] Masfufah, M., Rahardian, A., Maftuhah, S., Yulianto, E., Sumariyah, S., \& Nur, M. Analysis of ozone production for medical with double dielectric barrier discharge (DDBD) plasma technology against spiral - mesh electrode combination. AIP Conference Proceedings, 2197 (040004) (2020).

[15] Bhatta, R., Kayastha, R., Subedi, D. P., \& Joshi, R. Treatment of wastewater by ozone produced in dielectric barrier discharge. Journal of Chemistry, 2015(648162), 1-6 (2015).

[16] Subedi, D. P., Tyata, R. B., Khadgi, A., \& Wong, C. S. Treatment of water by dielectric barrier discharge. Journal of Science and Technology in the Tropics, 5, 117-123 (2009).

[17] KC, S. K., Sharma, S., Shrestha, R., \& Subedi, D. P. Electrical characterization of an atmospheric pressure plasma jet. Journal of Nepal Physical Society, 5 (1), 85-90 (2019). 